\title{
Oxidation of Mercury Across SCR Catalysts in Coal-Fired Power Plants Burning Low Rank Fuels
}

\author{
Quarterly Progress Report
}

$\begin{array}{ll}\text { Reporting Period Start Date } & \text { April 1, } 2004 \\ \text { Reporting Period End Date: } & \text { June 30, } 2004\end{array}$

\author{
Constance Senior \\ July 30, 2004 \\ DOE Cooperative Agreement No: DE- FC26-03NT41728 \\ Reaction Engineering International \\ 77 West 200 South, Suite 210 \\ Salt Lake City, UT 84101
}




\section{Disclaimer}

"This report was prepared as an account of work sponsored by an agency of the United States Government. Neither the United States Government nor any agency thereof, nor any of their employees, makes any warranty, express or implied, or assumes any legal liability or responsibility for the accuracy, completeness, or usefulness of any information, apparatus, product, or process disclosed, or represents that its use would not infringe privately owned rights. Reference herein to any specific commercial product, process, or service by trade name, trademark, manufacturer, or otherwise does not necessarily constitute or imply its endorsement, recommendation, or favoring by the United States Government or any agency thereof. The views and opinions of authors expressed herein do not necessarily state or reflect those of the United States Government or any agency thereof." 


\begin{abstract}
This is the sixth Quarterly Technical Report for DOE Cooperative Agreement No: DE-FC2603NT41728. The objective of this program is to measure the oxidation of mercury in flue gas across SCR catalyst in a coal-fired power plant burning low rank fuels using a slipstream reactor containing multiple commercial catalysts in parallel. The Electric Power Research Institute (EPRI) and Argillon $\mathrm{GmbH}$ are providing co-funding for this program. This program contains multiple tasks and good progress is being made on all fronts. During this quarter, a review of the available data on mercury oxidation across SCR catalysts from small, laboratory-scale experiments, pilot-scale slipstream reactors and full-scale power plants was carried out. Data from small-scale reactors obtained with both simulated flue gas and actual coal combustion flue gas demonstrated the importance of temperature, ammonia, space velocity and chlorine on mercury oxidation across SCR catalyst. SCR catalysts are, under certain circumstances, capable of driving mercury speciation toward the gas-phase equilibrium values at SCR temperatures. Evidence suggests that mercury does not always reach equilibrium at the outlet. There may be other factors that become apparent as more data become available.
\end{abstract}




\section{Table of Contents}

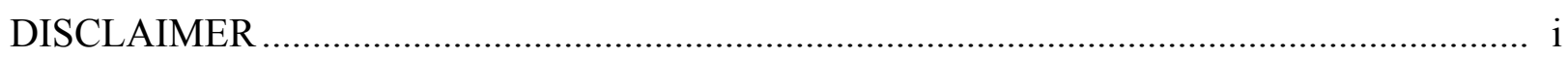

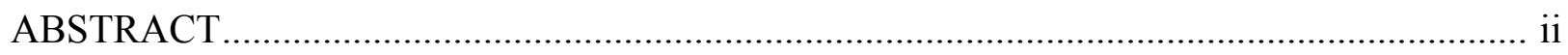

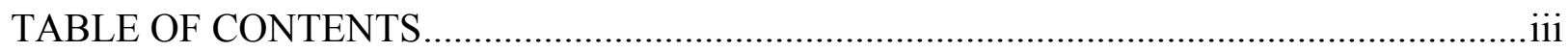

EXECUTIVE SUMMARY .................................................................................. 1

EXPERIMENTAL METHODS................................................................................ 2

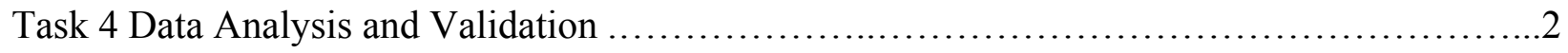

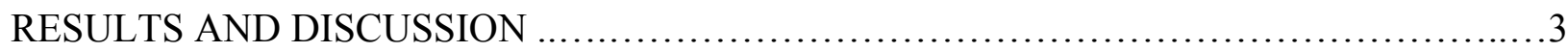

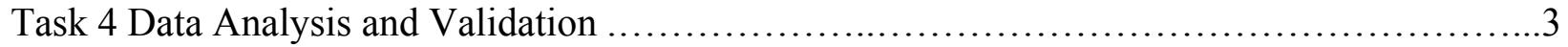

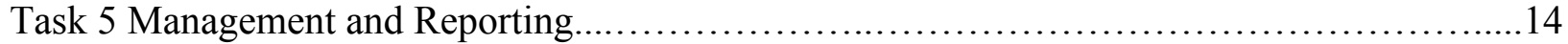

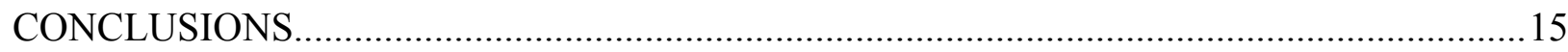

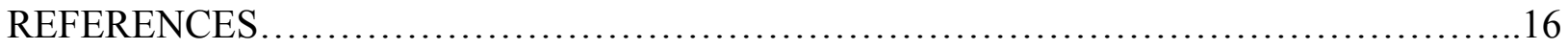

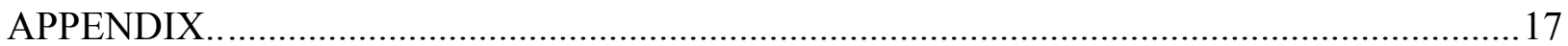




\section{Executive Summary}

This project received funding from the Department of Energy under Cooperative Agreement No: DE-FC26-03NT41728. The Electric Power Research Institute (EPRI) and Argillon GmbH are providing co-funding for this program. This project has a period of performance that started February 19, 2003 and continues through September 30, 2004.

Under a separate program (cooperative agreement DE-FC26-00NT40753), Reaction Engineering International (REI) has been funded by the Department of Energy to carry out research and development on $\mathrm{NO}_{\mathrm{x}}$ control options for coal-fired utility boilers. The objective of one of the tasks in the $\mathrm{NO}_{\mathrm{x}}$-control program is to evaluate and model SCR catalyst deactivation. REI will be responsible for six-month testing of multiple commercial catalysts simultaneously in a power plant slipstream reactor. This multi-catalyst reactor provides an ideal test bed for advancing the state of knowledge regarding mercury oxidation by SCR catalysts, with a focus on low rank fuels.

In this program, REI is using the multi-catalyst slipstream reactor to determine oxidation of mercury across six separate SCR catalysts at AEP's Rockport Unit 1. During the six-month testing under the existing $\mathrm{NO}_{\mathrm{x}}$-control program, two week-long sampling campaigns for mercury speciation will be carried out: at the beginning of the six-month period and at an intermediate point. URS will conduct the one-week campaigns to measure gaseous mercury speciation at the inlet and at the outlet of each catalyst chamber.

The specific project tasks are:

- Task 1 Test Preparation

- Task 2 Test Plan

- Task 3 Field Measurements of Mercury Speciation

- Task 4 Data Analysis and Validation

- Task 5 Management and Reporting

During the last three months, our accomplishments included a review of the available data on mercury oxidation across SCR catalysts from small, laboratory-scale experiments, pilot-scale slipstream reactors and full-scale power plants. Data from small-scale reactors obtained with both simulated flue gas and actual coal combustion flue gas demonstrated the importance of temperature, ammonia, space velocity and chlorine on mercury oxidation across SCR catalyst. SCR catalysts are, under certain circumstances, capable of driving mercury speciation toward the gas-phase equilibrium values at the SCR temperature. Measured mercury speciation at the outlet to full-scale SCR installations was shown to correlate well with the calculated equilibrium value, based on the SCR temperature and coal composition. Thus, the primary variables responsible for the formation of oxidized mercury at the outlet of the SCR are chlorine content of the coal and temperature. However, evidence suggests that mercury does not always reach equilibrium at the outlet. Some of the other factors that have been shown to affect mercury chemistry across SCR catalysts are the space velocity and the presence of ammonia. There may be other factors that become apparent as more data become available. 


\section{Experimental Methods}

Within this section we present in order, brief discussions on the different tasks that are contained within this program. For simplicity, the discussion items are presented in the order of the Tasks as outlined in our original proposal.

\section{Task 4 - Data Analysis and Validation}

As discussed in the quarterly report for January to March, 2004, laboratory ${ }^{1-3}$ and pilot-scale ab-7 $^{4-2}$ data have been collected on the behavior of mercury in SCR catalysts, in addition to the pilotscale data obtained in this program. Data have been collected from measurements of mercury speciation across SCRs in six full-scale power plants under funding by DOE NETL and EPRI ${ }^{8,9}$, from other utility data and from other data reported in the literature. ${ }^{10}$ The tables in the Appendix provide details of the design and operating conditions, and the measured mercury speciation and oxidation in these catalysts. Further information can be found in References 8 through 10. The ammonia-to-NO ratios for these full-scale systems are not given; however, since the full-scale data all come from operating electric utility boilers, the $\mathrm{NO}_{\mathrm{x}}$ reductions achieved by the SCR catalysts would be of a similar magnitude. Most of the boilers fired US eastern bituminous coals with a range of sulfur from $0.7 \mathrm{wt} \%$ to $3.8 \mathrm{wt} \%$; chlorine contents ranged from 250 to $1,600 \mu \mathrm{g} / \mathrm{g}$ (dry basis). Boiler E1 fired a South African bituminous coal with $46 \mu \mathrm{g} / \mathrm{g} \mathrm{Cl}$; boiler $\mathrm{S} 1$ fired a US subbituminous coal whose $\mathrm{Cl}$ content was estimated from measured gas-phase $\mathrm{HCl}$ as $23 \mu \mathrm{g} / \mathrm{g}$. 


\section{Results and Discussion}

\section{Task 4 - Data Analysis and Validation}

\section{Simulated Flue Gas Experimental Data}

Laboratory experiments cannot duplicate all the conditions present in flue gas from a full-scale power plant. However, certain important reaction pathways can be isolated in laboratory-scale experiments as long as there is confidence that the laboratory conditions are relevant to full-scale conditions. There have been few laboratory-scale investigations of mercury chemistry across SCR catalysts to date, but much can be learned from those few that have been undertaken.

Elemental mercury is adsorbed by the catalyst until some steady state is reached. ${ }^{1,2}$ The amount of mercury adsorbed appears to be related to the $\mathrm{HCl}$ content of the flue gas. In laboratory experiments carried out by Hocquel and coworkers, ${ }^{2,3}$ mercury was measured at the inlet and outlet of commercial catalysts where a simulated flue gas containing varying levels of $\mathrm{HCl}$ was passed through the catalyst for ten minutes. At high concentrations ( 20 to $75 \mathrm{ppm})$ of $\mathrm{HCl}$, the outlet mercury concentration was almost equal to the inlet mercury. At low concentrations ( $\sim 0.2$ to $2 \mathrm{ppm}$ ) of $\mathrm{HCl}$, however, the catalyst initially adsorbed 80 to 90 percent of the incoming mercury. The presence of $\mathrm{HCl}$ therefore reduced the amount of mercury adsorbed on the catalyst. Transient experiments in the same laboratory showed that a step increase in the $\mathrm{HCl}$ concentration caused an increase in mercury exiting the catalyst in concentrations above the inlet level of mercury.

Laboratory experiments by Lee and co-workers ${ }^{1}$ demonstrated that when $\mathrm{HCl}$ and $\mathrm{Hg}^{0}$ (in a simulated flue gas mixture) entered the SCR reactor, oxidized mercury exited the reactor. When there was no $\mathrm{HCl}$ in the same simulated flue gas, very little oxidized mercury was formed at the outlet, suggesting that $\mathrm{HCl}$ reacted with the adsorbed mercury, prompting it to desorb.

Steady-state experiments by Hocquel et al. ${ }^{2}$ showed the effect of $\mathrm{HCl}$ concentration in simulated flue gas on the amount of $\mathrm{HgCl}_{2}$ exiting a laboratory SCR reactor, with and without $\mathrm{SO}_{2}$ present. $\mathrm{HCl}$ concentration had a major impact on the amount of $\mathrm{HgCl}_{2}$ exiting the catalyst. Several different types of catalysts were tested; the type of catalyst affected the oxidation of $\mathrm{Hg}^{0}$ via $\mathrm{HCl}$. This may be due to differences in pore structure among different catalysts as well as the concentrations of different metal oxides $\left(\mathrm{V}, \mathrm{W}, \mathrm{Mo}\right.$ ) in the catalyst. $\mathrm{SO}_{2}$ had a minor impact on mercury oxidation in these experiments.

Other experiments in the same laboratory ${ }^{3}$ using three layers of commercial monolith catalyst, in which mercury oxidation was measured in between layers, show the effect of temperature, $\mathrm{HCl}$ and ammonia on mercury oxidation. Figure 1 shows the amount of $\mathrm{Hg}^{0}$ oxidation across all three layers of the catalyst as a function of temperature for two different flue gas compositions, one containing $10 \mathrm{ppm} \mathrm{HCl}$ and the other $62 \mathrm{ppm} \mathrm{HCl}$. The simulated flue gas also contained $2.8 \% \mathrm{O}_{2}, 3 \% \mathrm{H}_{2} \mathrm{O}, 524$ to 544 ppm $\mathrm{SO}_{2}, 395$ to 430 ppm $\mathrm{NO}_{\mathrm{x}}, 38-53 \mathrm{ppm} \mathrm{CO}, 15$ to $24 \mu \mathrm{g} / \mathrm{Nm}^{3}$ mercury and ammonia. The molar ratio of ammonia to NO was 1 and the space velocity was 4800 to $5600 \mathrm{hr}^{-1}$. Mercury oxidation increased when the inlet $\mathrm{HCl}$ concentration was increased. The figure shows the effect of $\mathrm{HCl}$ concentration and temperature: mercury oxidation increased at lower temperatures and this effect was more pronounced at lower $\mathrm{HCl}$ concentration. 


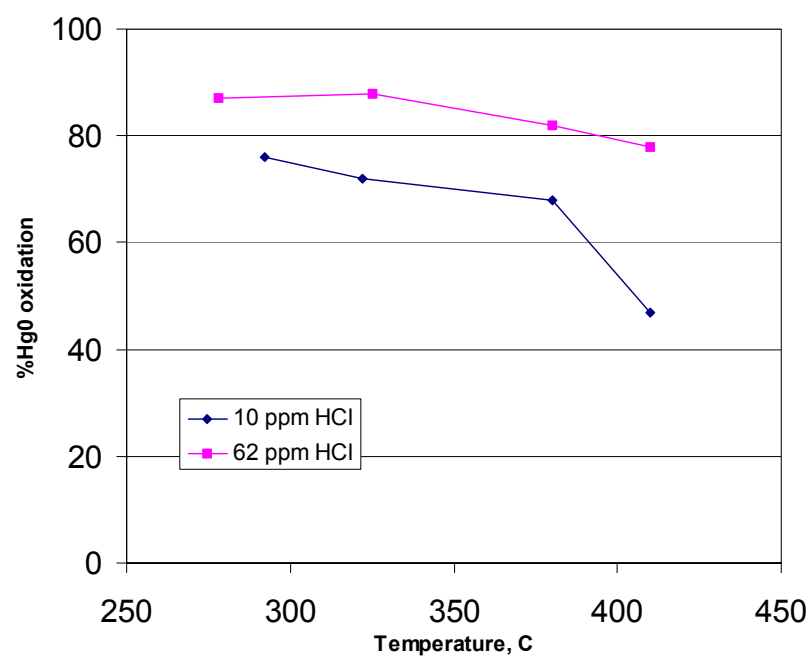

Figure 1. Mercury oxidation across laboratory SCR catalyst as a function of temperature and $\mathrm{HCl}$ concentration in simulated flue gas mixture with ammonia. [See Reference 3 for details].

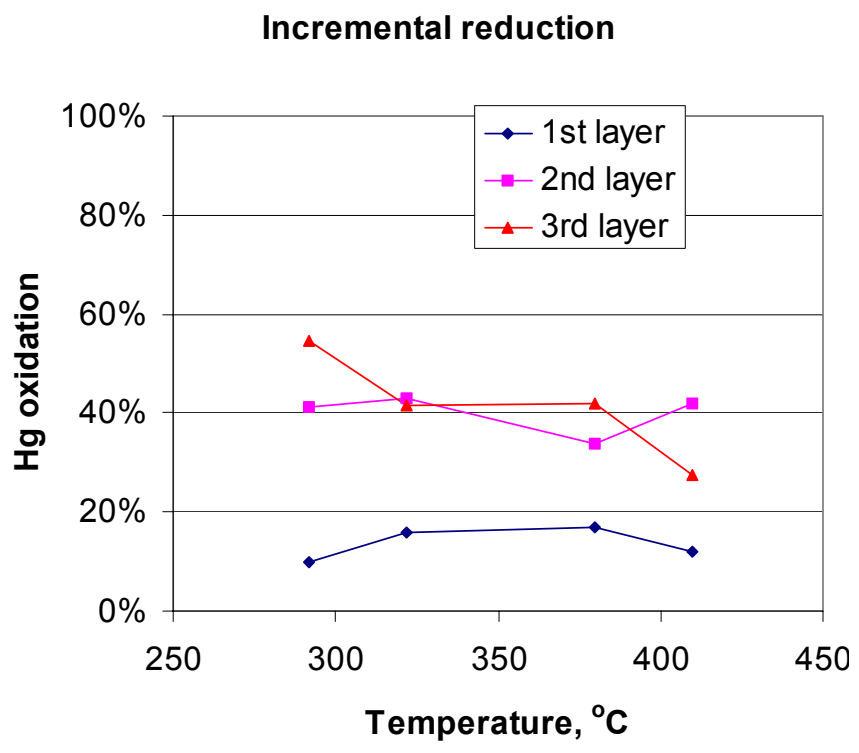

Figure 2. Mercury oxidation per layer of catalyst as a function of temperature in simulated flue gas mixture with ammonia, and 10 ppm HCl. [See Reference 3 for details].
In the SCR reactor, $\mathrm{NO}$ is reduced along the length of the reactor and ammonia is consumed. Thus the first layer of the catalyst would have a higher concentration of ammonia than the second layer. Figure 2 shows the incremental mercury oxidation across each layer in this laboratory experiment. The first layer (with the highest ammonia concentration) showed the lowest mercury oxidation. The second and third layers, showed higher oxidation. The presence of ammonia appears to affect the oxidation of mercury across the catalyst. Since it is known that ammonia adsorbs on metal oxide sites on the catalyst, this suggests that mercury (elemental or perhaps $\mathrm{HgO}$ ) may be bound to one of the same active sites that bind ammonia (probably vanadium oxide but other metal oxides may be involved as well). There are not enough laboratory experiments on the effect of $\mathrm{SO}_{2}$ or $\mathrm{SO}_{3}$ on mercury oxidation by SCR catalysts. The effects of $\mathrm{HCl}$ and ammonia seem clear enough and can also be seen in the results of pilot and full-scale measurements.

The effect of temperature and ammonia can be observed in laboratory measurements ${ }^{4}$ using simulated flue gases (Table 1) with commercial $\mathrm{Ti} / \mathrm{V}$-based SCR catalyst; extruded honeycomb catalyst with a $10-\mathrm{mm}$ cell pitch. The simulated Powder River Basin (PRB) subbituminous flue gas had lower $\mathrm{HCl}$ and $\mathrm{SO}_{2}$ than the simulated bituminous flue gas. Figure 3 shows the measured mercury oxidation for an extruded monolith catalyst with the two different simulated flue gas compositions. The simulated bituminous flue gas produced higher mercury oxidation, as might be suspected from the higher $\mathrm{HCl}$-content. Mercury oxidation increased as temperature decreased; the highest oxidation was at $315^{\circ} \mathrm{C}\left(600^{\circ} \mathrm{F}\right)$. Without ammonia in the simulated flue gas mixture, the mercury oxidation increased for both the simulated bituminous and PRB flue gas compositions. 
Table 1. Simulated flue gas compositions used in experiments in Reference 4.

\begin{tabular}{|l|c|c|}
\hline & $\begin{array}{c}\text { Simulated PRB } \\
\text { Subbituminous }\end{array}$ & $\begin{array}{c}\text { Simulated } \\
\text { Bituminous }\end{array}$ \\
\hline $\mathrm{SO}_{2}$ & $400 \mathrm{ppm}$ & $1600 \mathrm{ppm}$ \\
\hline $\mathrm{HCl}$ & $2 \mathrm{ppm}$ & $50 \mathrm{ppm}$ \\
\hline $\mathrm{NO}_{\mathrm{x}}$ & $400 \mathrm{ppm}$ & $400 \mathrm{ppm}$ \\
\hline $\mathrm{H}_{2} \mathrm{O}$ & $7 \%$ & $7 \%$ \\
\hline $\mathrm{CO}_{2}$ & $12 \%$ & $12 \%$ \\
\hline $\mathrm{O}_{2}$ & $5 \%$ & $5 \%$ \\
\hline $\mathrm{Hg}^{0}$ & $20-40 \mu \mathrm{g} / \mathrm{Nm}^{3}$ & $20-40 \mu \mathrm{g} / \mathrm{Nm}^{3}$ \\
\hline $\mathrm{N}_{2}$ & Balance & Balance \\
\hline
\end{tabular}

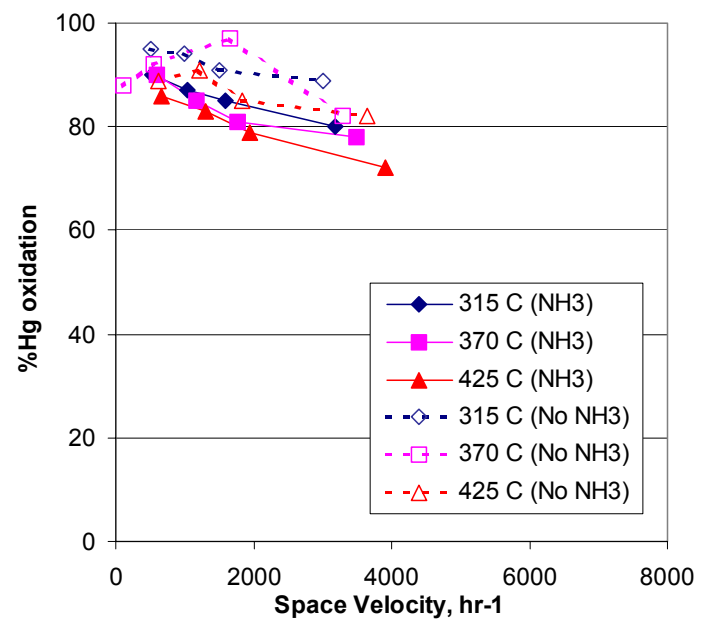

(a) Catalyst C1 with PRB flue

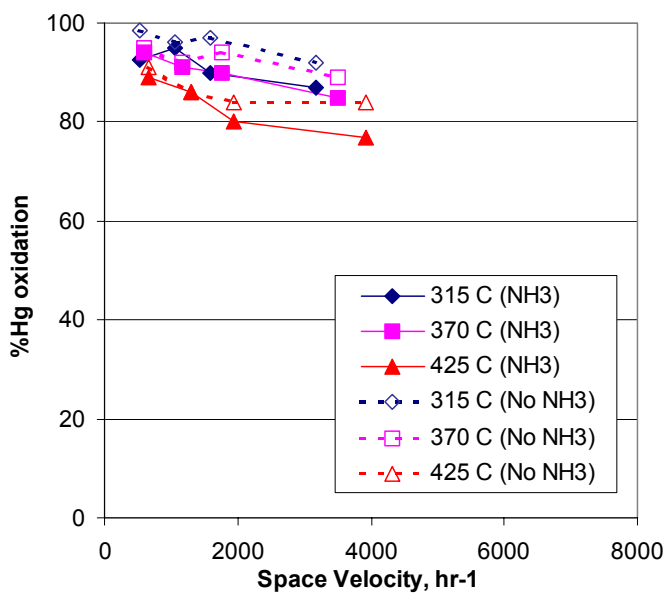

(b) Catalyst $\mathrm{C} 1$ with bituminous flue gas

Figure 3. Mercury oxidation of extruded monolith catalyst as function of temperature and space velocity with $\left(\mathrm{NH}_{3} / \mathrm{NO}=1\right)$ and without ammonia for simulated flue gas: (a) PRB composition gas and (b) eastern bituminous gas composition. [See Reference 4 for details]. 


\section{Combustion-Derived Flue Gas Experimental Data}

Simulated flue gas does not always produce mercury oxidation behavior that is consistent with that observed in flue gases derived from full-scale power plants. Measurements of mercury speciation have been made across small-scale reactors using flue gas from full-scale power plants instead of simulated flue gas. ${ }^{4-7}$

The earliest investigation on a pilot-scale coal combustor equipped with an SCR reactor, ${ }^{5}$ showed significant changes in mercury speciation at the inlet to the ESP when burning eastern bituminous coals, but little change in mercury speciation across the SCR when a PRB coal was burned.

There are differences in the levels of mercury oxidation at a given space velocity between simulated and actual flue gas; furthermore the dependence of oxidation on space velocity is different between simulated and actual flue gas. Figure 4 compares the observed mercury oxidation across the extruded catalyst with the simulated PRB flue gas (Table 1) and a power plant that burns a PRB coal. ${ }^{4}$ The differences between the two sets of experimental results might be due to components in the actual flue gas (ash, $\mathrm{SO}_{3}$, other halogens) that may interfere with mercury adsorption or oxidation at higher space velocities (shorter residence times) perhaps because of competition for active sites.

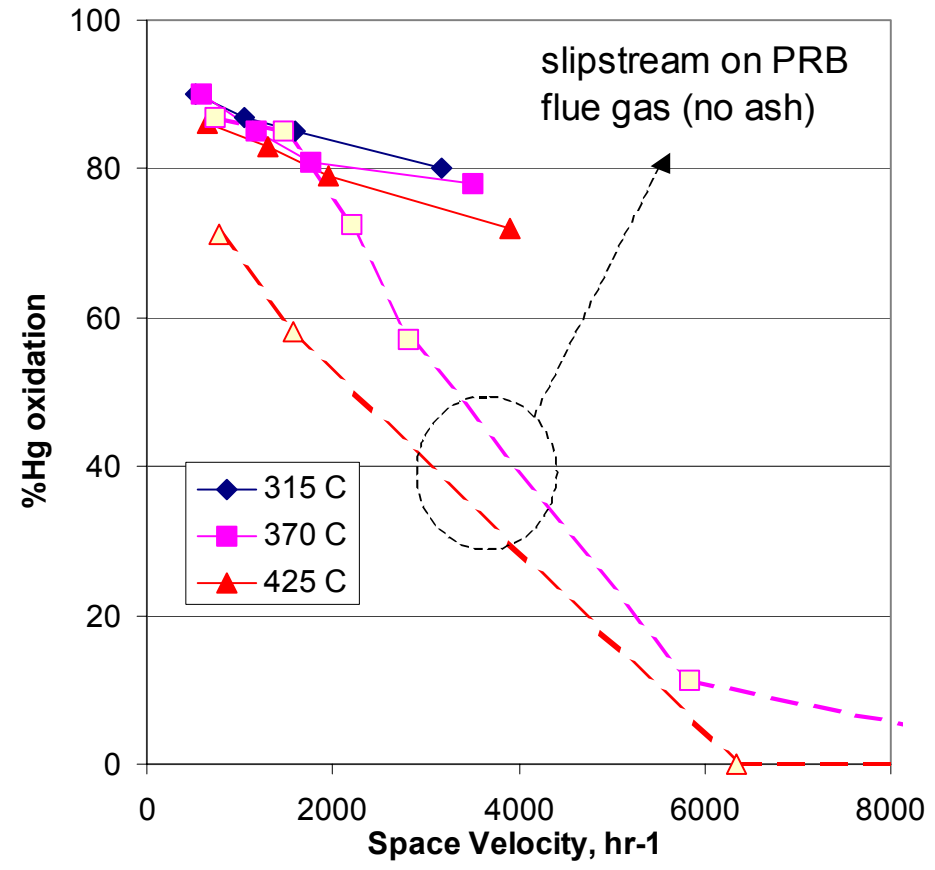

Figure 4. Mercury oxidation of extruded monolith catalyst as function of temperature and space velocity with ammonia $\left(\mathrm{NH}_{3} / \mathrm{NO}=1\right)$, comparison of oxidation in simulated PRB flue gas and flue gas from power plant burning PRB coal. [See Reference 4 for details].
In this program, mercury speciation was measured across five commercial SCR catalysts and a blank monolith in parallel. The multicatalyst reactor was deployed at AEP's Rockport plant, which burned a blend of 87 $\%$ subbituminous PRB coal and $13 \%$ bituminous coal. The chlorine content of the blend was 100 to $240 \mu \mathrm{g} / \mathrm{g}$ on a dry basis. Mercury measurements were carried out when the catalysts were relatively new, corresponding to about 300 hours of operation. In general, the commercial catalysts all appeared capable of achieving about $90 \%$ $\mathrm{NO}_{\mathrm{x}}$ reduction at a space velocity of 3,000 hr-1, which is typical of full-scale installations. For the fresh commercial catalysts, oxidation of mercury was in the range of $25 \%$ to $65 \%$ at typical full-scale space velocities. A blank monolith showed no 


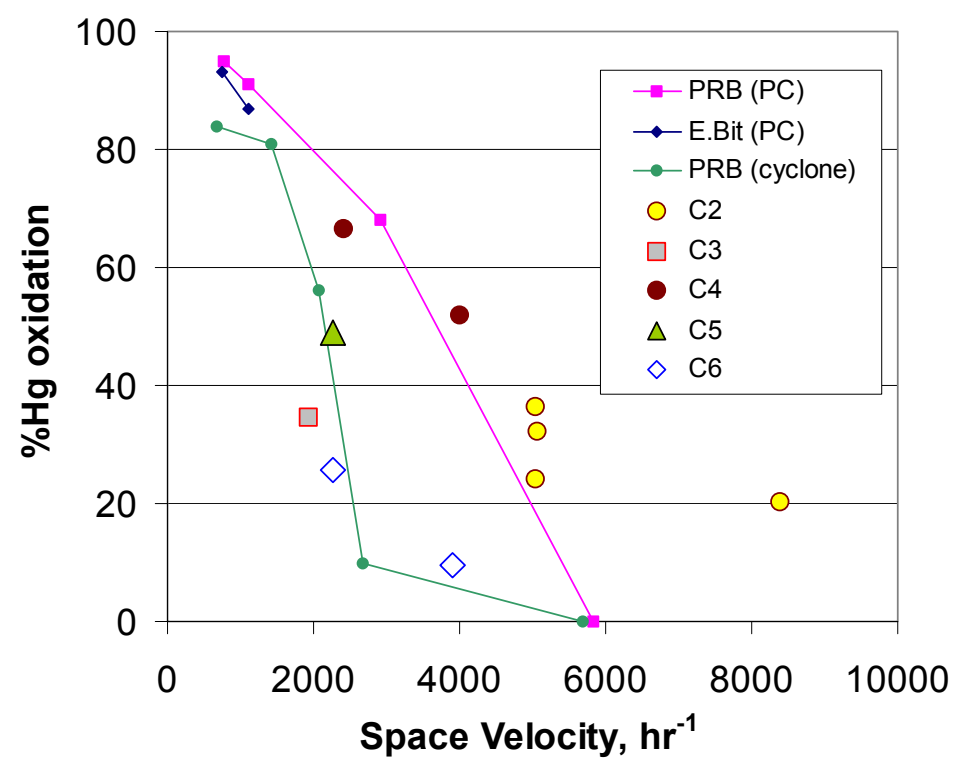

Figure 5. Mercury oxidation as a function of space velocity from power plant flue gas measurements at $370^{\circ} \mathrm{C}\left(7_{00}^{\circ} \mathrm{F}\right)$ with ammonia, ${ }^{7}$ shown in with solid lines, and multicatalyst slipstream, shown with data points for individual catalysts, at $340-350^{\circ} \mathrm{C}\left(645-660^{\circ} \mathrm{F}\right)$.

oxidation of mercury under any conditions. All catalysts showed higher mercury oxidation without ammonia, consistent with other measurements.

In Figure 5, the observed mercury oxidation from the multicatalyst slipstream reactor is compared with data from a small-scale reactor, in which the same type of catalyst (the extruded honeycomb) was tested at three different full-scale power plants. ${ }^{7}$ The multicatalyst reactor data fall between the Eastern bituminous and PRB cyclone curves for the singlecatalyst reactor and generally follow the same trend of mercury oxidation with space velocity.

Data from small-scale reactors obtained with both simulated

flue gas and actual coal combustion flue gas highlight the importance of temperature, ammonia, space velocity and chlorine on mercury oxidation across SCR catalyst. Laboratory-scale data suggests that $\mathrm{HCl}$ is an important factor in promoting mercury oxidation across SCR catalysts and that $\mathrm{SO}_{2}$ is not important. In light of these factors, full-scale data will be examined to determine if these parameters have a significant impact in full-scale systems.

\section{Full-Scale Data}

The full-scale data show an effect of ammonia on mercury oxidation, as have the laboratory and pilot-scale work discussed previously. Figure 6 shows three of the plants in which mercury speciation measurements were made with and without ammonia. The amount of oxidation of elemental mercury decreased when ammonia was added to the flue gas upstream of the catalyst. Operating power plants are unlikely to operate SCRs without ammonia; if high levels of NOx reduction are not needed - in ozone season, for example - the catalyst is typically bypassed. The value of the measurements without ammonia is in advancing the understanding of the behavior of mercury in SCR catalysts. The same mechanisms appear to be at work in the full-scale SCR reactor as in laboratory and slipstream reactors, which helps to provide confidence in the use of laboratory and pilot-scale data. 


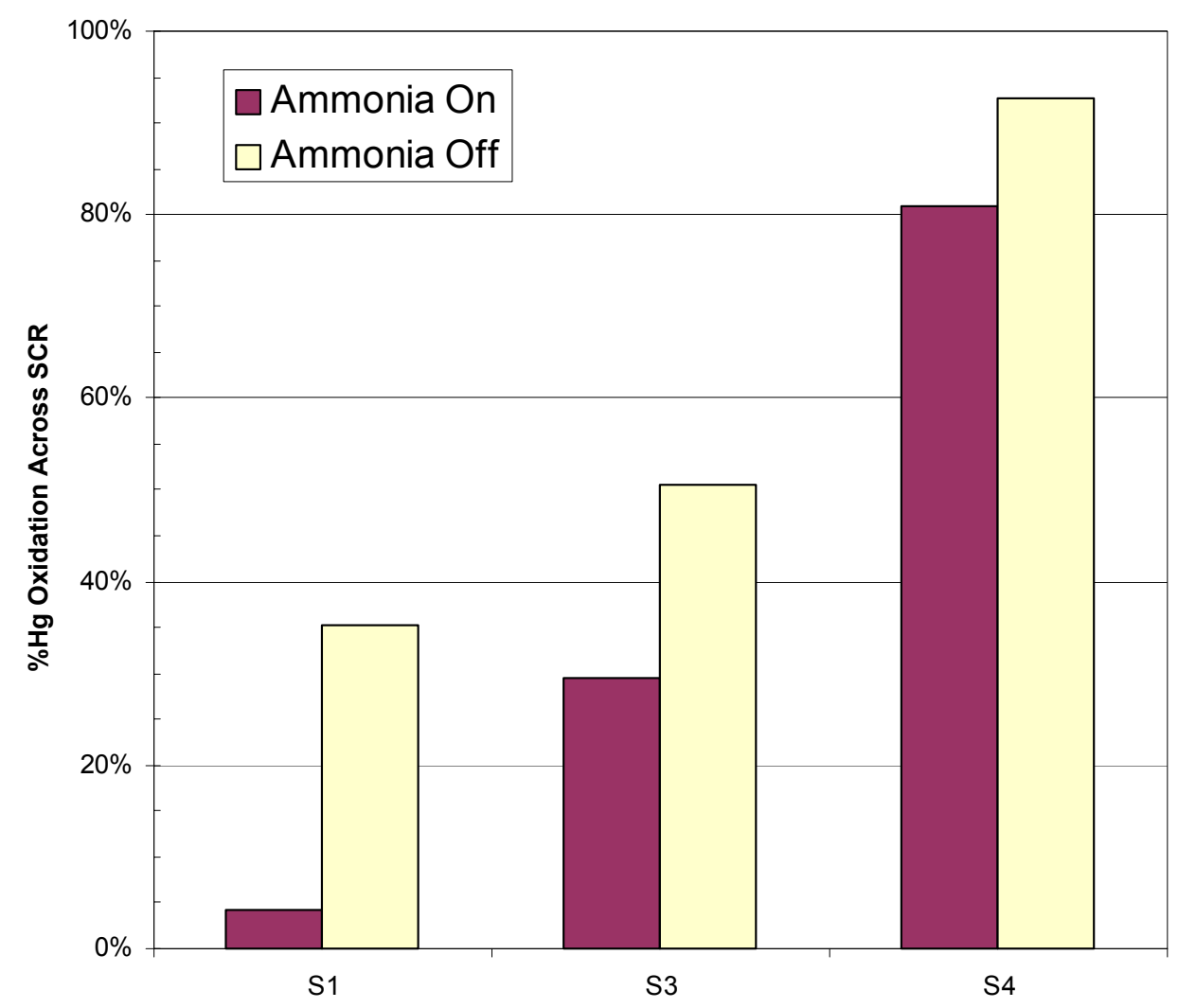

Figure 6. Mercury oxidation across SCR catalyst from full-scale power plants with and without ammonia; plant S1 burns subbituminous coal; plants S3 and S4 burn bituminous coals.

In laboratory experiments, the effect of $\mathrm{HCl}$ concentration on mercury oxidation was observed to be very pronounced; this was supported indirectly by pilot-scale data using flue gas from fullscale power plants. Figure 7 displays the mercury oxidation from full-scale SCRs as a function of coal chlorine content. Mercury oxidation was calculated as the percent change in elemental mercury in the flue gas between the inlet and outlet of the SCR. The full-scale data have been divided into low-sulfur $(<1 \mathrm{wt} \% \mathrm{~S}$ in the coal) and high-sulfur $(>1 \mathrm{wt} \% \mathrm{~S}$ in the coal). The figure suggests that there may be a relationship between coal chlorine content and mercury oxidation across SCR catalysts. However, there is considerable scatter in the data. Sulfur content of the coal does not appear to have an influence on mercury oxidation.

In searching for a way to understand the full-scale data and the dependence of mercury oxidation on process parameters, we should take note of the role that catalysts play in chemical reactions: catalysts push a chemical reaction toward equilibrium. The effect of $\mathrm{HCl}$ on mercury oxidation across SCR catalysts is clear in laboratory-scale experiments. Therefore, it would be prudent to examine the equilibrium distribution of mercury species in the gas-phase at SCR reactor temperatures. 


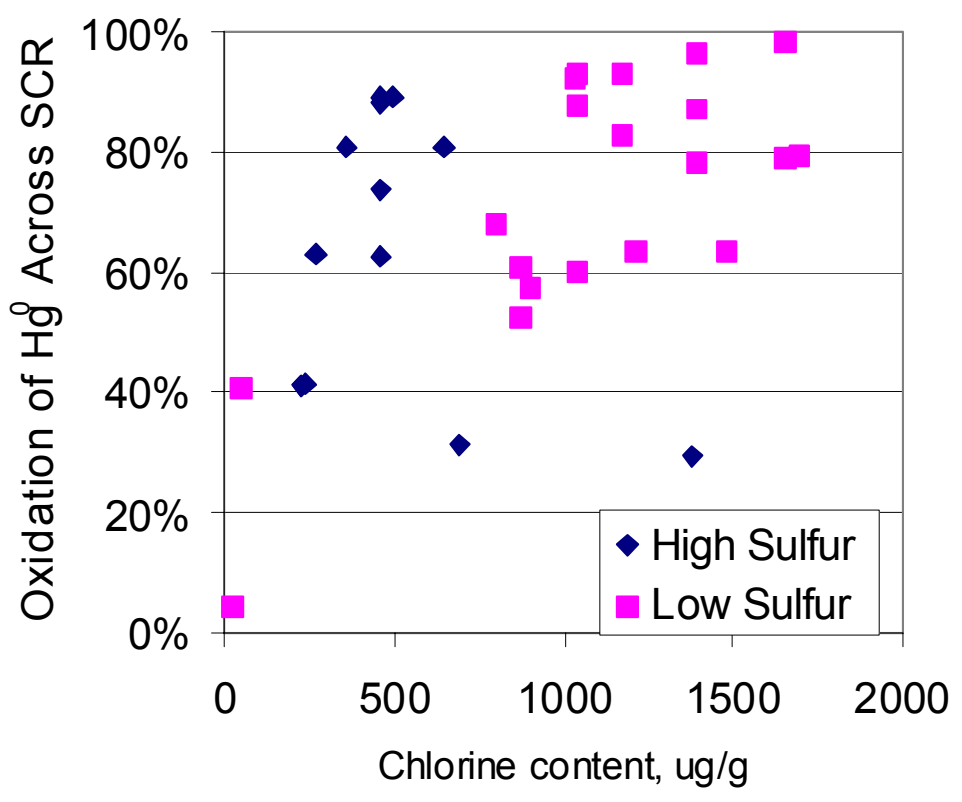

Figure 7. Mercury oxidation across SCR catalyst from full-scale power plants as a function of coal chlorine content and sulfur content.

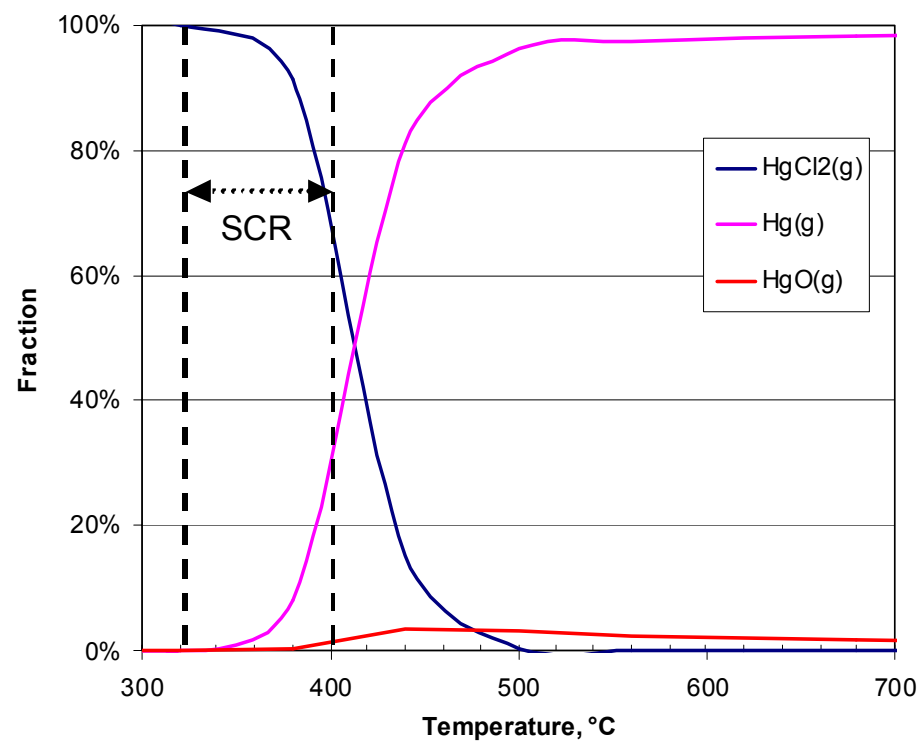

Figure 8. Equilibrium speciation of gaseous mercury compounds in flue gas as a function of temperature for subbituminous coal (see Table 2 for bulk composition).
Thermodynamic equilibrium calculations were carried out using the HSC package ${ }^{11}$ for the overall compositions given in Table A-1. A typical result for flue gas from the subbituminous coal is shown in Figure 8. The same general behavior is observed for bituminous coal. At temperatures greater than approximately $500^{\circ} \mathrm{C} \quad\left(930^{\circ} \mathrm{F}\right)$ $\mathrm{Hg}^{0}$ and $\mathrm{HgO}$ are the thermodynamically stable species of mercury; $\mathrm{HgO}$ is a minor component. At temperatures below approximately $300^{\circ} \mathrm{C}$ $\left(570^{\circ} \mathrm{F}\right) \quad \mathrm{HgCl}_{2}$ is thermodynamically stable. A characteristic of this system is the temperature at which the curves for $\mathrm{Hg}^{0}$ and $\mathrm{HgCl}_{2}$ cross. This temperature is sensitive to the total chlorine in the system and not very sensitive to the mercury concentration, as illustrated in Figure 9, which shows the calculated fraction of elemental mercury at a fixed temperature as a function of the equivalent coal chlorine content (for combustion conditions corresponding to Table 2). The figure also illustrates the similarity between speciation with a bituminous coal flue gas composition and a subbituminous coal flue gas composition. Thus, temperature and chlorine content have the greatest impact on mercury speciation in flue gas under equilibrium conditions. 
Table 2. Bulk gas compositions used for equilibrium calculations.

\begin{tabular}{|l|c|c|}
\hline & Subbituminous & Bituminous \\
\hline $\mathrm{N}_{2}[\mathrm{vol} \%]$ & 70.6 & 75.4 \\
\hline $\mathrm{CO}_{2}[\mathrm{vol} \%]$ & 13.9 & 14.6 \\
\hline $\mathrm{H}_{2} \mathrm{O}[\mathrm{vol} \%]$ & 12.3 & 6.8 \\
\hline $\mathrm{O}_{2}[\mathrm{vol} \%]$ & 3.0 & 3.0 \\
\hline $\mathrm{SO}_{2}[\mathrm{ppm}]$ & 350 & 1000 \\
\hline $\mathrm{HCl}[\mathrm{ppm}]$ & 1.75 & 31 \\
\hline $\mathrm{Hg}[\mathrm{ppb}]$ & 0.2 & 0.2 \\
\hline
\end{tabular}

At the inlet to an SCR reactor, mercury species are not in equilibrium because of the high cooling rates experienced by the flue gas upstream of the SCR reactor. This can be seen clearly in Figure 10, which plots the fraction of elemental mercury at the inlet to full-scale SCR reactors as a function of the coal chlorine content. For comparison, the predicted equilibrium compositions for the bituminous coal (Table A-1) at different temperatures are shown. In general, mercury does not appear to be in equilibrium at the inlet to SCR reactors.

Equilibrium at $370 \mathrm{C}(700 \mathrm{~F})$

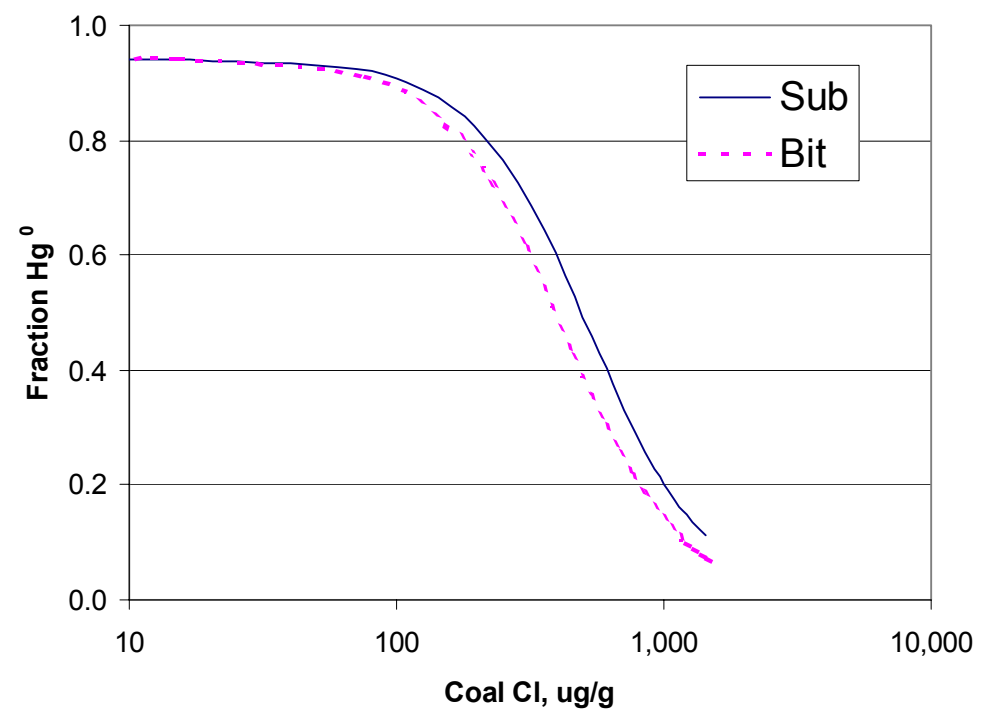

Figure 9. Fraction of elemental mercury in flue gas at equilibrium $\left(\mathrm{T}=350^{\circ} \mathrm{C}\right)$ as a function of coal chlorine content (see Table 2 for bulk composition). 


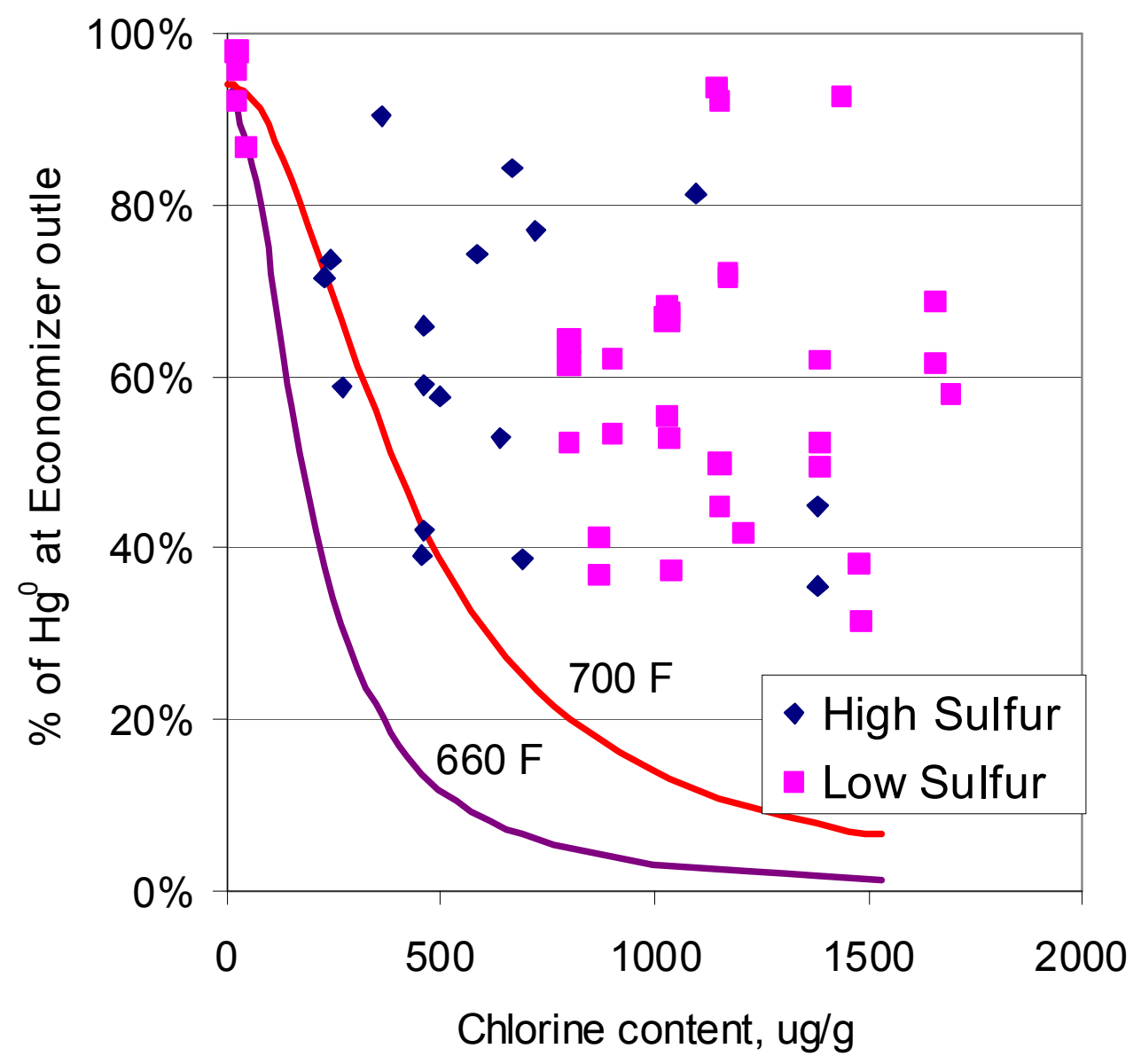

Figure 10. Fraction of mercury as elemental at the outlet of SCR reactors; solid lines are calculated equilibrium for bituminous coal flue gas at various temperatures.

Mercury speciation at the outlet to SCR reactors, in contrast, comes very close to equilibrium, as shown in Figure 11. Again, the equilibrium predictions are compared with measured values of speciation. Good agreement is shown between the predicted and measured mercury speciation for the data points corresponding to temperatures in the range of $330^{\circ} \mathrm{C}$ to $370^{\circ} \mathrm{C}\left(625^{\circ} \mathrm{F}\right.$ to $\left.700^{\circ} \mathrm{F}\right)$. The point that corresponds to a reactor temperature in the range of $390^{\circ} \mathrm{C}$ to $400^{\circ} \mathrm{C}(730$ to $750^{\circ} \mathrm{F}$ ) shows a higher fraction of $\mathrm{Hg}^{0}$ at the reactor outlet, as would be expected. Considering the scatter in the mercury speciation at the inlet to the reactor (Figure 10), it is no wonder that the predicted oxidation of elemental mercury is so scattered. However, the prediction of outlet speciation appears to be possible with some accuracy.

Pilot and laboratory-scale data have demonstrated an effect of ammonia on mercury oxidation across SCR catalysts. Unfortunately, there are only limited full-scale data on mercury speciation and oxidation without ammonia present. Figure 12 shows speciation data from three of the six full-scale plants with and without ammonia present. Again, the specific ammonia-to-NO ratio was not given in the descriptions of the full-scale plants, but this ratio is typically on the order of 0.9 in commercial installations. The amount of $\mathrm{Hg}^{0}$ at equilibrium (given the temperature and chlorine content of the coal) is shown in the figure as a horizontal line on each bar. Generally 
the mercury speciation at the outlet of the reactor is closer to the equilibrium state without ammonia. More full-scale data with and without ammonia are needed to reach a conclusion about the effect of ammonia in full-scale SCRs. Based on pilot-scale slipstream data, an effect of ammonia is expected.

(a) Ammonia On

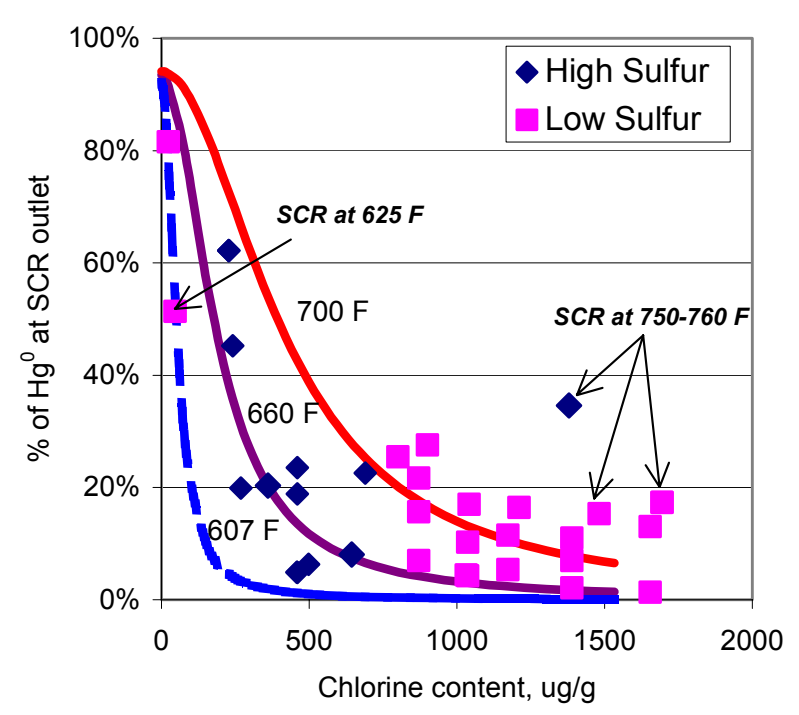

(b) Ammonia Off

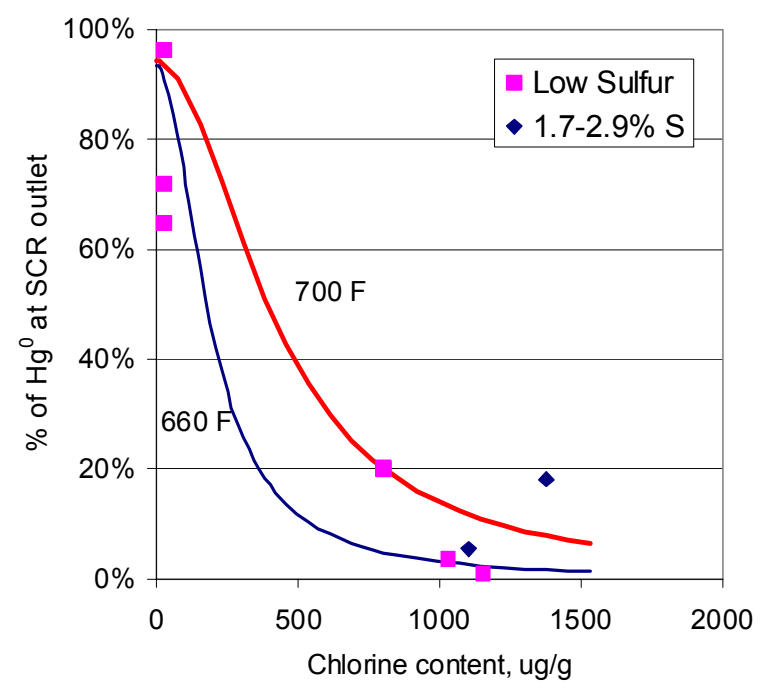

Figure 11. Fraction of mercury as elemental at the outlet of SCR reactors; solid lines are calculated equilibrium for bituminous coal flue gas at various temperatures. (a) Ammonia on; (b) Ammonia off. 


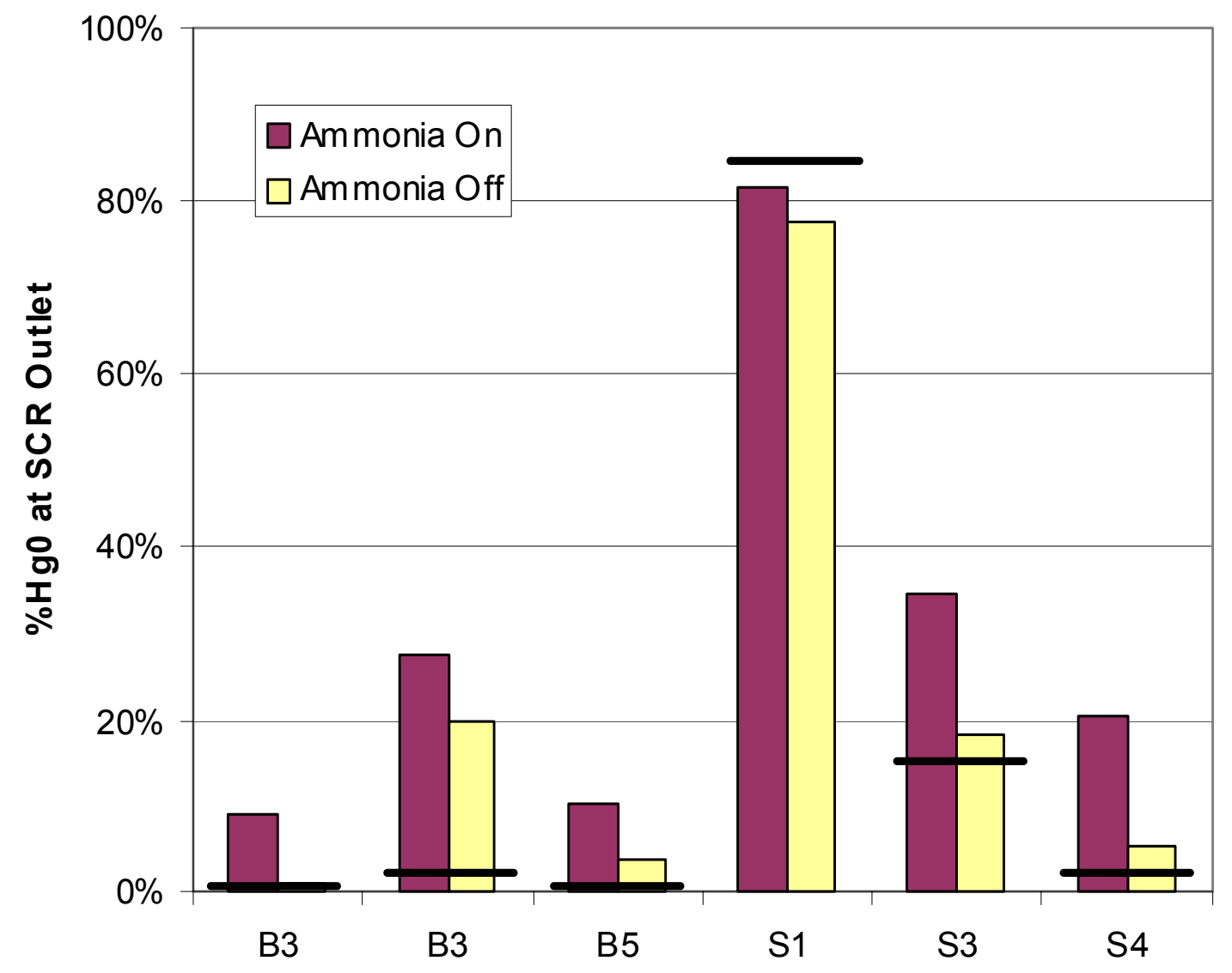

Figure 12. Fraction of mercury as elemental at the outlet to SCR reactors: comparison of measured values with and without ammonia; equilibrium values are indicated by solid lines. 


\section{4}

\section{Task 5 - Management and Reporting}

Results from portions of this research program have been reported to industry through technical presentations at conferences. One paper was presented at the Coal Utilization \& Fuel Systems Conference in Clearwater, Florida, April 18-22, 2004:

- Constance Senior and Temi Linjewile, "Oxidation Of Mercury Across SCR Catalysts In Coal-Fired Power Plants."

Two papers were submitted to technical journals based on the work in this program:

- Constance Senior and Temi Linjewile, "Oxidation of Mercury across SCR Catalysts in a Coal-Fired Power Plant Burning a Blend of Subbituminous and Bituminous Coals", submitted to Fuel Processing Technology

- Constance Senior, "Oxidation of Mercury across SCR Catalysts in Coal-Fired Power Plants", submitted to Journal of the Air \& Waste Management Association 


\section{Conclusions}

A review of the available data on mercury oxidation across SCR catalysts from small, laboratory-scale experiments, pilot-scale slipstream reactors and full-scale power plants was carried out. SCR catalysts are, under certain circumstances, capable of driving mercury speciation toward the gas-phase equilibrium values at the SCR temperature. Measured mercury speciation at the outlet to full-scale SCR installations was shown to correlate well with the calculated equilibrium value, based on the SCR temperature and coal composition. Thus, the primary variables responsible for the formation of oxidized mercury at the outlet of the SCR were determined to be chlorine content of the coal and temperature. However, evidence suggests that mercury does not always reach equilibrium at the outlet of SCR catalysts. Some of the other factors that have been shown to affect mercury chemistry across SCR catalysts are the space velocity and the presence of ammonia. There may be other factors, such as the sulfur content of the coal, that become apparent as more data become available. Catalyst properties may be important, including: the mix between vanadium oxides and other oxides in the catalyst; the pore size distribution; and catalyst deactivation with time.

The results of this analysis of the available data on mercury speciation across SCR catalysts suggest strategies for maximizing the amount of oxidized mercury at the exit of SCR catalysts. The chief of these is to increase the chlorine content of the flue gas, either through blending lowchlorine coal with high-chlorine coal or additives. Lowering the temperature is another option, but this may not be practical in many utility boilers. Furthermore, NO reduction across SCR catalysts decreases with temperature.

\section{Plans for Next Quarter}

- The preliminary mercury mechanism will be implemented in REI's one-dimensional SCR model. 


\section{References}

1. Lee. C.W., Srivastava, R.K., Ghorishi, S.B., Hastings, T.W., Stevens, F.M. "Study of Speciation of Mercury under Simulated SCR NO Emission Control Conditions," presented at the DOE-EPRI-U.S. EPA -A\&WMA Combined Power Plant Air Pollutant Control Symposium - The Mega Symposium, Washington, DC, May 19-22, 2003.

2. Hocquel, M., Unterberger, S., Hein, K.R.G. "Effects of Mercury on SCR-catalysts," presented at the 2002 Conference on Selective Catalytic Reduction (SCR) and Selective Non-Catalytic Reduction (SNCR) for NOx Control, Pittsburgh, PA, May 15-16, 2002.

3. Bock, J., Hocquel, M., Unterberger, S., Hein, K.R.G. "Mercury Oxidation Across SCR Catalysts of Flue Gas with Varying $\mathrm{HCl}$ Concentrations," presented at the DOE-EPRI-U.S. EPA -A\&WMA Combined Power Plant Air Pollutant Control Symposium - The Mega Symposium, Washington, DC, May 19-22, 2003.

4. Richardson, C., Machalek, T., Miller, S., Dene, C., Chang, R. "Effect of $\mathrm{NO}_{\mathrm{x}}$ Control Processes on Mercury Speciation in Flue Gas," presented at the Air Quality III Meeting, Washington, D.C., September 10-13, 2002.

5. Laudal, D.L., Pavlish, J.H., Chu, P., "Pilot-Scale Evaluation of the Impact of Selective Catalytic Reduction for $\mathrm{NO}_{\mathrm{x}}$ on Mercury Speciation," paper presented at the Air \& Waste Management Association 94 ${ }^{\text {th }}$ Annual Conference, Orlando, Florida, June 24-28, 2001.

6. Machalek, T., Ramavajjala, M., Richardson, M., Richardson, Dene, C., Goeckner, B., Anderson, H., Morris, E., "Pilot Evaluation of Flue Gas Mercury Reactions Across an SCR Unit," presented at the DOE-EPRI-U.S. EPA -A\&WMA Combined Power Plant Air Pollutant Control Symposium - The Mega Symposium, Washington, DC, May 19-22, 2003.

7. Richardson, C., Machalek, T., Miller, S., Dene, C., Chang, R "Effect of $\mathrm{NO}_{\mathrm{x}}$ Control Processes on Mercury Speciation in Utility Flue Gas”' J.Air Waste Manage. Assoc., 2002, 52, 941-947

8. Laudal, D. Effect of Selective Catalytic Reduction on Mercury, 2002 Field Studies Update, EPRI, Palo Alto, CA: 2002. Product ID 1005558.

9. Chu, P., Laudal, D., Brickett, L., Lee, C.W. "Power Plant Evaluation of the Effect of SCR Technology on Mercury," presented at the DOE-EPRI-U.S. EPA -A\&WMA Combined Power Plant Air Pollutant Control Symposium - The Mega Symposium, Washington, DC, May 19-22, 2003.

10. La Marca, C., Cioni, M., Pintus, N., Rossi, N., Malloggi, S., Barbieri, A. "Macro and MicroPollutant Emission Reduction in Coal-Fired Power Plant," presented at Seventh International Conference on Energy for a Clean Environment (Clean Air 2003), Lisbon, Portugal, July 710, 2003.

11. HSC Chemistry, Outokumpu Research Oy, P.O. Box 60, Pori, 28101, Finland, http://www.outokumpu.com/template/Page 8092.asp [accessed 11 June 2004]. 


\section{Appendix}

Full-Scale Mercury Speciation Data 
Table A-1. Full-Scale Data, with ammonia on. [Boiler E1 from Reference 10, Boilers S1 through S6 from References 8,9; Boilers B3 through B5 from other utility data.]

\begin{tabular}{|c|c|c|c|c|c|c|c|c|c|c|c|c|c|c|c|}
\hline \multirow[b]{2}{*}{ Boiler } & \multirow[b]{2}{*}{ MW } & \multirow[b]{2}{*}{$\begin{array}{l}\text { Coal } \\
\text { Rank }\end{array}$} & \multirow[b]{2}{*}{$\begin{array}{l}\text { Coal, } \\
\% \mathrm{~S}, \mathrm{AR}\end{array}$} & \multirow[b]{2}{*}{\begin{tabular}{|c|} 
Coal, Hg \\
ug/g (dry)
\end{tabular}} & \multirow[b]{2}{*}{$\begin{array}{c}\text { Coal, Cl } \\
\text { ug/g (dry) }\end{array}$} & \multicolumn{2}{|c|}{ Temperatures, F } & \multirow[b]{2}{*}{$\begin{array}{c}\text { SCR } \\
\text { Space } \\
\text { velocity, } \\
\text { 1/hr }\end{array}$} & \multirow[b]{2}{*}{$\begin{array}{l}\text { SCR } \\
\text { inlet }\end{array}$} & \multirow{2}{*}{\begin{tabular}{|c|}
$\begin{array}{c}\text { Speciation } \\
-\% \mathbf{H g}^{0}\end{array}$ \\
SCR outlet
\end{tabular}} & \multirow[b]{2}{*}{$\begin{array}{l}\text { ESP } \\
\text { Inlet }\end{array}$} & \multirow[b]{2}{*}{ Stack } & \multirow{2}{*}{\multicolumn{2}{|c|}{\begin{tabular}{|c|}
$\begin{array}{c}\text { Oxidation } \\
\text { Across }\end{array}$ \\
\\
Air \\
Heater \\
\end{tabular}}} & \multirow[b]{2}{*}{$\begin{array}{c}\text { Air } \\
\text { Heater }+ \\
\text { ESP }\end{array}$} \\
\hline & & & & & & $\begin{array}{c}\text { Econ Out } \\
\text { or SCR In }\end{array}$ & SCR Out & & & & & & & & \\
\hline E1 & 320 & Bit & 0.65 & 0.078 & 46 & 626 & 626 & 3,420 & $86.8 \%$ & $51.4 \%$ & $39.3 \%$ & $71.5 \%$ & $40.8 \%$ & $23.5 \%$ & $41.1 \%$ \\
\hline $\mathrm{S} 1$ & 600 & Sub & 0.19 & 0.102 & 23 & 685 & 675 & 1,800 & $95.8 \%$ & & & $81.7 \%$ & & & \\
\hline S1 & 600 & Sub & 0.19 & 0.102 & 23 & 685 & 675 & 1,800 & $91.9 \%$ & $81.6 \%$ & $4.3 \%$ & $77.0 \%$ & $4.2 \%$ & $95.1 \%$ & $80.6 \%$ \\
\hline $\mathrm{S} 1$ & 600 & Sub & 0.19 & 0.102 & 23 & 685 & 675 & 1,800 & $91.9 \%$ & $81.6 \%$ & $4.3 \%$ & $77.0 \%$ & $4.2 \%$ & $95.1 \%$ & $80.6 \%$ \\
\hline $\mathrm{S} 2$ & 1300 & Bit & 4 & 0.11 & 498 & 661 & 678 & 2,125 & $57.7 \%$ & $6.3 \%$ & $3.9 \%$ & $77.8 \%$ & $89.3 \%$ & $37.5 \%$ & \\
\hline $\mathrm{S} 2$ & 1300 & Bit & 4 & 0.11 & 459 & 661 & 678 & 2,125 & $39.3 \%$ & $5.0 \%$ & $1.6 \%$ & & $88.1 \%$ & $60.0 \%$ & \\
\hline $\mathrm{S} 2$ & 1300 & Bit & 3.6 & 0.13 & 690 & 661 & 678 & 2,125 & $38.7 \%$ & $22.6 \%$ & & & $31.3 \%$ & & \\
\hline $\mathrm{S} 2$ & 1300 & Bit & 3.9 & 0.168 & 643 & 661 & 678 & 2,125 & $52.9 \%$ & $8.1 \%$ & $2.7 \%$ & $50.0 \%$ & $80.8 \%$ & $71.4 \%$ & \\
\hline S3 & 750 & Bit & 1.67 & 0.4 & 1380 & 730 & 751 & 3,930 & $44.9 \%$ & $34.6 \%$ & $8.8 \%$ & $19.0 \%$ & $29.4 \%$ & $71.7 \%$ & \\
\hline $\mathrm{S} 4$ & 650 & Bit & 2.8 & 0.17 & 269 & 693 & 692 & 2,275 & $58.7 \%$ & $19.9 \%$ & $4.1 \%$ & $77.8 \%$ & $63.0 \%$ & $83.3 \%$ & \\
\hline S4 & 650 & Bit & 2.8 & 0.15 & 241 & 693 & 692 & 2,275 & $73.6 \%$ & $45.2 \%$ & & & $41.6 \%$ & & \\
\hline S4 & 650 & Bit & 2.7 & 0.16 & 228 & 693 & 692 & 2,275 & $71.6 \%$ & $62.2 \%$ & $3.6 \%$ & $75.0 \%$ & $41.0 \%$ & $89.1 \%$ & \\
\hline $\mathrm{S} 4$ & 650 & Bit & 2.7 & 0.16 & 228 & 693 & 692 & 2,275 & $71.6 \%$ & $62.2 \%$ & $4.2 \%$ & $66.7 \%$ & $41.0 \%$ & $91.3 \%$ & \\
\hline $\mathrm{S} 4$ & 650 & Bit & 2.88 & 0.131 & 750 & 677 & 669 & 2,275 & $90.3 \%$ & $20.3 \%$ & $7.7 \%$ & $93.3 \%$ & $80.9 \%$ & $56.0 \%$ & \\
\hline S5 & 684 & Bit & 3.6 & & 460 & 649 & 653 & 3,700 & $42.1 \%$ & $4.8 \%$ & & $66.7 \%$ & $89.3 \%$ & & $0.0 \%$ \\
\hline S5 & 684 & Bit & 3.6 & & 460 & 649 & 653 & 3,700 & $59.1 \%$ & $23.6 \%$ & & & $62.5 \%$ & & \\
\hline S5 & 684 & Bit & 3.6 & & 460 & 649 & 653 & 3,700 & $65.9 \%$ & $18.9 \%$ & $6.3 \%$ & $75.0 \%$ & $73.6 \%$ & $66.7 \%$ & $62.5 \%$ \\
\hline S6 & 700 & Bit & 0.9 & & 1,041 & 701 & 702 & 3,800 & $37.4 \%$ & $17.0 \%$ & $8.0 \%$ & $12.6 \%$ & $60.0 \%$ & $56.3 \%$ & $25.0 \%$ \\
\hline S6 & 700 & Bit & 0.9 & & 871 & 701 & 702 & 3,800 & $41.3 \%$ & $21.7 \%$ & $4.3 \%$ & $16.7 \%$ & $52.6 \%$ & $77.8 \%$ & $16.7 \%$ \\
\hline S6 & 700 & Bit & 0.9 & & 871 & 701 & 702 & 3,800 & $36.9 \%$ & $15.7 \%$ & $4.3 \%$ & $16.7 \%$ & $61.0 \%$ & $75.0 \%$ & $6.3 \%$ \\
\hline S6 & 700 & Bit & 0.9 & 0.084 & 1,210 & 701 & 702 & 3,800 & $41.7 \%$ & $16.4 \%$ & $2.7 \%$ & $3.4 \%$ & $63.3 \%$ & $72.7 \%$ & $54.5 \%$ \\
\hline
\end{tabular}




\section{Table A-1 [Continued]}

\begin{tabular}{|c|c|c|c|c|c|c|c|c|c|c|c|c|c|c|c|}
\hline \multirow[b]{2}{*}{ Boiler } & \multirow[b]{2}{*}{ MW } & \multirow[b]{2}{*}{$\begin{array}{l}\text { Coal } \\
\text { Rank } \\
\end{array}$} & \multirow[b]{2}{*}{$\begin{array}{c}\text { Coal, } \\
\% \text { S, AR } \\
\end{array}$} & \multirow[b]{2}{*}{$\begin{array}{c}\text { Coal, Hg } \\
\text { ug/g (dry) }\end{array}$} & \multirow[b]{2}{*}{$\begin{array}{c}\text { Coal, Cl } \\
\text { ug/g (dry) }\end{array}$} & \multicolumn{2}{|c|}{ Temperatures, F } & \multirow[b]{2}{*}{$\begin{array}{c}\text { SCR } \\
\text { Space } \\
\text { velocity, } \\
1 / \mathbf{h r} \\
\end{array}$} & \multirow[b]{2}{*}{$\begin{array}{l}\text { SCR } \\
\text { inlet }\end{array}$} & \multirow{2}{*}{\begin{tabular}{|c|}
$\begin{array}{c}\text { Speciation } \\
-\% \mathrm{Hg}^{0}\end{array}$ \\
SCR outlet \\
\end{tabular}} & \multirow[b]{2}{*}{$\begin{array}{l}\text { ESP } \\
\text { Inlet } \\
\end{array}$} & \multirow[b]{2}{*}{ Stack } & \multirow{2}{*}{\multicolumn{2}{|c|}{\begin{tabular}{|c|}
$\begin{array}{c}\text { Oxidation } \\
\text { Across }\end{array}$ \\
\\
Air \\
Heater \\
\end{tabular}}} & \multirow[b]{2}{*}{$\begin{array}{c}\text { Air } \\
\text { Heater }+ \\
\text { ESP }\end{array}$} \\
\hline & & & & & & $\begin{array}{c}\text { Econ Out } \\
\text { or SCR In }\end{array}$ & SCR Out & & & & & & & & \\
\hline B3 & 900 & Bit & 0.81 & 0.11 & 800 & 621 & & 1,515 & $63.6 \%$ & $25.4 \%$ & & $27.0 \%$ & $68.1 \%$ & & $63.7 \%$ \\
\hline B3 & 1300 & Bit & 0.79 & 0.10 & 900 & 677 & & 2,188 & $62.1 \%$ & $27.6 \%$ & & $27.7 \%$ & $57.3 \%$ & & $56.1 \%$ \\
\hline B3 & 900 & Bit & 0.72 & 0.075 & 1,655 & 631 & & 1,515 & $61.4 \%$ & $13.0 \%$ & & $5.7 \%$ & $79.1 \%$ & & $90.7 \%$ \\
\hline B3 & 1300 & Bit & 0.72 & 0.075 & 1,655 & 681 & & 2,188 & $68.8 \%$ & $1.3 \%$ & & $2.4 \%$ & $98.2 \%$ & & $96.4 \%$ \\
\hline B3 & 900 & Bit & 0.67 & 0.076 & 1,389 & 620 & & 1,515 & $62.0 \%$ & $2.1 \%$ & & $2.2 \%$ & $96.5 \%$ & & $96.5 \%$ \\
\hline B3 & 1300 & Bit & 0.67 & 0.076 & 1,389 & 669 & & 2,188 & $49.5 \%$ & $11.0 \%$ & & $2.0 \%$ & $78.3 \%$ & & $95.7 \%$ \\
\hline B3 & 1300 & Bit & 0.67 & 0.076 & 1,389 & 659 & & 3,800 & $52.4 \%$ & $7.0 \%$ & & $1.9 \%$ & $87.3 \%$ & & $96.4 \%$ \\
\hline B4 & 650 & Bit & 0.87 & 0.07 & 1,694 & 773 & 762 & 5,252 & $57.8 \%$ & $17.3 \%$ & & $7.8 \%$ & $79.4 \%$ & $53.8 \%$ & \\
\hline B4 & 650 & Bit & 0.87 & 0.07 & 1,694 & 773 & 762 & 5,252 & $57.8 \%$ & $17.3 \%$ & & $22.1 \%$ & $79.4 \%$ & $-46.2 \%$ & \\
\hline B4 & 650 & Bit & 0.87 & 0.07 & 1,479 & 772 & 762 & 5,252 & $31.4 \%$ & $15.4 \%$ & & $8.5 \%$ & $63.6 \%$ & $50.0 \%$ & \\
\hline B5 & 1300 & Bit & 0.73 & 0.069 & 1,173 & 667 & & 1,990 & $72.1 \%$ & $5.4 \%$ & & $16.3 \%$ & $93.2 \%$ & & $-133.3 \%$ \\
\hline B5 & 1300 & Bit & 0.73 & 0.069 & 1,173 & 642 & & 1,990 & $71.4 \%$ & $11.5 \%$ & & $18.4 \%$ & $82.9 \%$ & & $-16.7 \%$ \\
\hline B5 & 900 & Bit & 0.69 & 0.064 & 1,032 & 611 & & 1,378 & $68.4 \%$ & $4.4 \%$ & & $9.1 \%$ & $92.3 \%$ & & $-66.7 \%$ \\
\hline B5 & 900 & Bit & 0.61 & 0.056 & 1,036 & 616 & & 1,378 & $52.8 \%$ & $4.3 \%$ & & $10.4 \%$ & $92.9 \%$ & & $-150.0 \%$ \\
\hline B5 & 1300 & Bit & 0.61 & 0.056 & 1,036 & 674 & & 1,990 & $67.3 \%$ & $10.3 \%$ & & $6.7 \%$ & $87.9 \%$ & & $25.0 \%$ \\
\hline
\end{tabular}


Table A-2. Full-Scale Data, without ammonia on [Boilers S1, S3, S4 from References 8,9; Boilers B3 and B5 from other utility data].

\begin{tabular}{|c|c|c|c|c|c|c|c|c|c|c|c|c|c|c|c|}
\hline & & & & & & Tempera & tures, F & & & $\begin{array}{c}\text { Speciation } \\
-\% \mathrm{Hg}^{\mathbf{0}} \\
\end{array}$ & & & & $\begin{array}{c}\text { Oxidation } \\
\text { Across } \\
\end{array}$ & \\
\hline Boiler & MW & $\begin{array}{l}\text { Coal } \\
\text { Rank }\end{array}$ & $\begin{array}{c}\text { Coal, } \\
\% \mathrm{~S}, \mathrm{AR}\end{array}$ & $\begin{array}{c}\text { Coal, Hg } \\
\text { ug/g (dry) }\end{array}$ & $\begin{array}{c}\text { Coal, CI } \\
\text { ug/g (dry) }\end{array}$ & $\begin{array}{l}\text { Econ Out } \\
\text { or SCR In }\end{array}$ & SCR Out & $\begin{array}{c}\text { SCR } \\
\text { Space } \\
\text { velocity, } \\
\text { 1/hr }\end{array}$ & $\begin{array}{l}\text { SCR } \\
\text { inlet }\end{array}$ & SCR outlet & $\begin{array}{l}\text { ESP } \\
\text { Inlet }\end{array}$ & Stack & SCR & $\begin{array}{c}\text { Air } \\
\text { Heater }\end{array}$ & $\begin{array}{c}\text { Air } \\
\text { Heater + } \\
\text { ESP }\end{array}$ \\
\hline B3 & 1300 & Bit & 0.70 & 0.095 & 1,152 & 667 & & 2,188 & $50.0 \%$ & $1.1 \%$ & & $8.7 \%$ & $97.8 \%$ & & $82.2 \%$ \\
\hline B3 & 900 & Bit & 0.61 & 0.11 & 800 & 621 & & 1,515 & $64.2 \%$ & $20.2 \%$ & & $22.4 \%$ & $70.9 \%$ & & $67.4 \%$ \\
\hline B3 & 1300 & Bit & 0.79 & 0.10 & 800 & 671 & & 2,188 & $61.4 \%$ & $20.0 \%$ & & $23.8 \%$ & $71.4 \%$ & & $64.3 \%$ \\
\hline B5 & 1300 & Bit & 0.69 & 0.064 & 1,032 & 668 & & 1,990 & $66.7 \%$ & $3.8 \%$ & & $4.3 \%$ & $94.4 \%$ & & $0.0 \%$ \\
\hline S1 & 600 & Sub & 0.19 & 0.102 & 23 & 685 & 675 & 1,800 & $97.9 \%$ & $96.3 \%$ & $7.0 \%$ & $55.4 \%$ & $35.4 \%$ & $87.0 \%$ & $74.3 \%$ \\
\hline S1 & 600 & Sub & 0.19 & 0.102 & 23 & 685 & 675 & 1,800 & & $64.8 \%$ & & $55.4 \%$ & & & $77.0 \%$ \\
\hline S1 & 600 & Sub & 0.19 & 0.102 & 23 & 685 & 675 & 1,800 & & $71.9 \%$ & $3.7 \%$ & $28.3 \%$ & & $93.1 \%$ & $79.3 \%$ \\
\hline S3 & 750 & Bit & 1.67 & 0.4 & 1380 & 730 & 751 & 3,930 & $35.6 \%$ & $18.2 \%$ & $2.7 \%$ & $3.0 \%$ & $50.5 \%$ & $83.6 \%$ & \\
\hline S4 & 650 & Bit & 2.88 & 0.131 & 750 & 677 & 669 & 2,275 & $81.3 \%$ & $5.5 \%$ & $1.1 \%$ & $87.3 \%$ & $92.7 \%$ & $77.5 \%$ & \\
\hline
\end{tabular}

